\title{
ANALISIS KELAYAKAN PEMBUKAAN CABANG LABORATORIUM KLINIK KESEHATAN PATRA MEDICA DI KABUPATEN BOYOLALI
}

\author{
Muhamad Haris Maknun ${ }^{1}$, Hartomo Soewardi ${ }^{2}$, Ali Parkhan ${ }^{3}$ \\ Magister Teknik Industri, Fakultas Teknologi Industri Universitas Islam Indonesia ${ }^{1,2,3)}$ \\ Jl. Kaliurang Km. 14,5 Sleman, Yogyakarta 55584 \\ E - Mail : maknunharis.mpjateng@gmail.com
}

\begin{abstract}
Boyolali is one of a large city in central Java of Indonesia which its population increases annually by $31 \%$. This city has several health clinic includes antenatal clinics, general clinic and a clinical laboratory. Currently the numbers of clinics to service people are 77 clinics only. In fact, this district still requires on the other of 318 clinics that have an adequate qualification. Therefore it is crucial to establish some new clinics for satisfying the specified requirements by the district government. The purpose of this study is to analyze the feasibility of establishing a new clinical laboratory as an expansion of the existing clinic based on aspects of market, technics and technology, management, financial, legal and environment. Survey was conducted by distributing questioner and interview to a potential stakeholder. Non parametric statistical analysis is done to test some hypotheses at 5\% of significant level and $10 \%$ of margin of error. The result of this study shows that the establishment of clinic laboratory in Boyolali is feasible according to an analysis of whole aspects.
\end{abstract}

Keywords : Feasibility Analysis, Clinical Laboratory, Laboratory Expansion.

\section{PENDAHUluaN}

\subsection{Latar Belakang Masalah}

Dalam pembukaan dan pasal-pasal Undang-Undang Dasar Negara Republik Indonesia Tahun 1945 (UUD 1945) yaitu untuk "melindungi segenap bangsa Indonesia dan untuk memajukan kesejahteraan umum". Dalam Pasal 34 ayat 3 bahwa "Negara bertanggung jawab atas penyediaan fasilitas pelayanan kesehatan dan fasilitas pelayanan umum yang layak". Pasal 28 ayat 1 yang berbunyi "Setiap orang berhak hidup sejahtera lahir dan bathin, bertempat tinggal, dan mendapatkan lingkungan hidup yang baik dan sehat serta berhak memperoleh pelayanan kesehatan". Berdasarkan Pembukaan UUD 1945 dan beberapa pasal dalam UUD 1945, maka setiap Warga Negara Indonesia baik yang tinggal di Ibu Kota maupun di Kota - kota atau Kabupaten - kabupaten diseluruh Indonesia berhak mendapatkan sarana pelayanan kesehatan, termasuk juga Warga Masyarakat di Kabupaten Boyolali.

Berkaitan dengan sarana kesehatan yaitu jumlah klinik yang tersedia di Kabupaten Boyolali baru tersedia sejumlah 77 unit klinik (meliputi poliklinik kandungan, poliklinik umum dan laboratorium klinik kesehatan) hal ini belum memenuhi standar jumlah klinik minimal, yang mana jumlah klinik minimal yang dibutuhkan adalah sejumlah 318 unit klinik kesehatan (Keputusan Menteri Permukiman dan Prasarana Wilayah No.534/KPTS/M/2001). Pemerintah kabupaten boyolali juga menyediakan fasilitas kesehatan berupa BPJS, BPJS merupakan badan hukum yang dibentuk untuk menyelenggarakan jaminan sosial yang juga menjamin 2 macam jaminan sosial, yaitu jaminan kesehatan dan ketenaga kerjaan, dimana setiap orang termasuk orang asing yang bekerja paling singkat 6 bulan di Indonesia wajib menjadi peserta jaminan sosial (UU Nomor 24 Tahun 2011 tentang BPJS. Dengan semakin meningkatnya jumlah penduduk di Kabupaten Boyolali, maka perlu adanya penambahan sarana klinik kesehatan termasuk Laboratorium Klinik Kesehatan yang mana saran ini dapat dimanfaatkan bagi orang sehat yang butuh data kesehatan pribadi atau orang dalam keadaan kurang sehat. Untuk mendirikan Cabang 
Laboratorium Klinik Umum Pratama Patra Medica perlu adanya analisis kelayakan usaha sebagai informasi yang dapat membantu dalam pengambilan keputusan kelayakan dengan tujuan supaya dalam pengembangan usaha Laboratorium Klinik Kesehatan tersebut proses usahanya kedepan dapat memenuhi kelayakan baik dari Aspek Pasar, Aspek Manajemen, Aspek Teknis dan teknologi, Aspek Finansial, Apsek Hukum maupun Aspek Lingkungan, dapat optimal dalam pelayanan kesehatan bagi masyarakat di Kabupaten Boyolali.

\section{LANDASAN TEORI}

\subsection{Definisi Studi Kelayakan}

Menurut Umar, Husein (2003) Studi kelayakan proyek merupakan penelitian tentang layak atau tidaknya suatu proyek dibangun untuk jangka waktu tertentu. Studi kelayakan bisnis merupakan penelitian terhadap rencana bisnis yang tidak hanya menganalisis layak atau tidak layak bisnis dibangun, tetapi juga saat dioperasionalkan secara rutin dalam rangka pencapaian keuntungan yang maksimal untuk jangka waktu yang tidak ditentukan.

\subsection{Analisis Aspek Pasar}

Pemasaran adalah suatu proses sosial dan manajerial yang didalamnya individu dan kelompok mendapatkan apa yang mereka butuhkan dan diinginkan dengan menciptakan, menawarkan dan mempertukar produk yang bernilai dengan pihak lain Menurut (Kotler,1997). Lebih lanjut menurut Kotler (1997) ada bermacam - macam pasar diantaranya yaitu :

1. Pasar potensial (potential market).

2. Pasar yang tersedia (available market).

3. Pasar sasaran (target market).

\subsection{Analisis Aspek Teknik dan Teknologi}

Aspek teknis membahas tentang lokasi proyek, luas produksi, lay out pabrik dan pemilahan jenis teknologi dan equipment (Husnan dan Muhamad, 2000).

\subsection{Analisis Aspek Manajemen}

Manajemen Sumber Daya Manusia adalah ilmu dan seni mengatur hubungan dan peranan tenaga kerja agar efektif dan efisien membantu terwujudnya tujuan perusahaan, karyawan dan masyarakat (Hasibuan, 2010).

Fungsi - fungsi manajemen dapat diuraikan sebagai berikut (Kasmir dan Jakfar (2012) : Perencanaan (Planning), Pengorganisasian (Organizing), Pelaksanaan (Actuating) dan Pengawasan (Leading).

\subsection{Analisis Aspek Keuangan}

Tujuan menganalisis aspek finansial dari analisis kelayakan usaha adalah untuk menentukan rencana investasi melalui perhitungan biaya dan manfaat yang diharapkan dengan membandingkan antara pengeluaran dan pendapat, seperti ketersediaan dana, biaya modal, kemampuan usaha untuk membayar kembali dana tersebut dalam jangka waktu yang telah ditentukan dan menilai apakah usaha akan dapat dikembangkan terus (Umar, 2001).

\subsection{Analisis Aspek Hukum (Yuridis)}

Tujuan dari aspek hukum adalah untuk meneliti keabsahan, kesempurnaan, dan keaslian dari dokumen - dokumen yang dimiliki. Secara umum dokumen - dokumen yang akan diteliti sehubungan dengan aspek hukum ini sebagai berikut (Kasmir dan Jakfar, 2012) : Badan Hukum, Bukti Diri, Tanda Daftar Perusahaan, NPWP, Izin Perusahaan.

\subsection{Analisis Aspek Lingkungan Hidup}

Aspek lingkungan mengkaji Analisis mengenai dampak lingkungan (AMDAL) adalah kajian mengenai dampak besar dalama kegiatan yang direncanakan pada lingkungan hidup yang diperlukan bagi proses pengambilan keputusan tentang 


\section{METODOLOGI PENELITIAN}

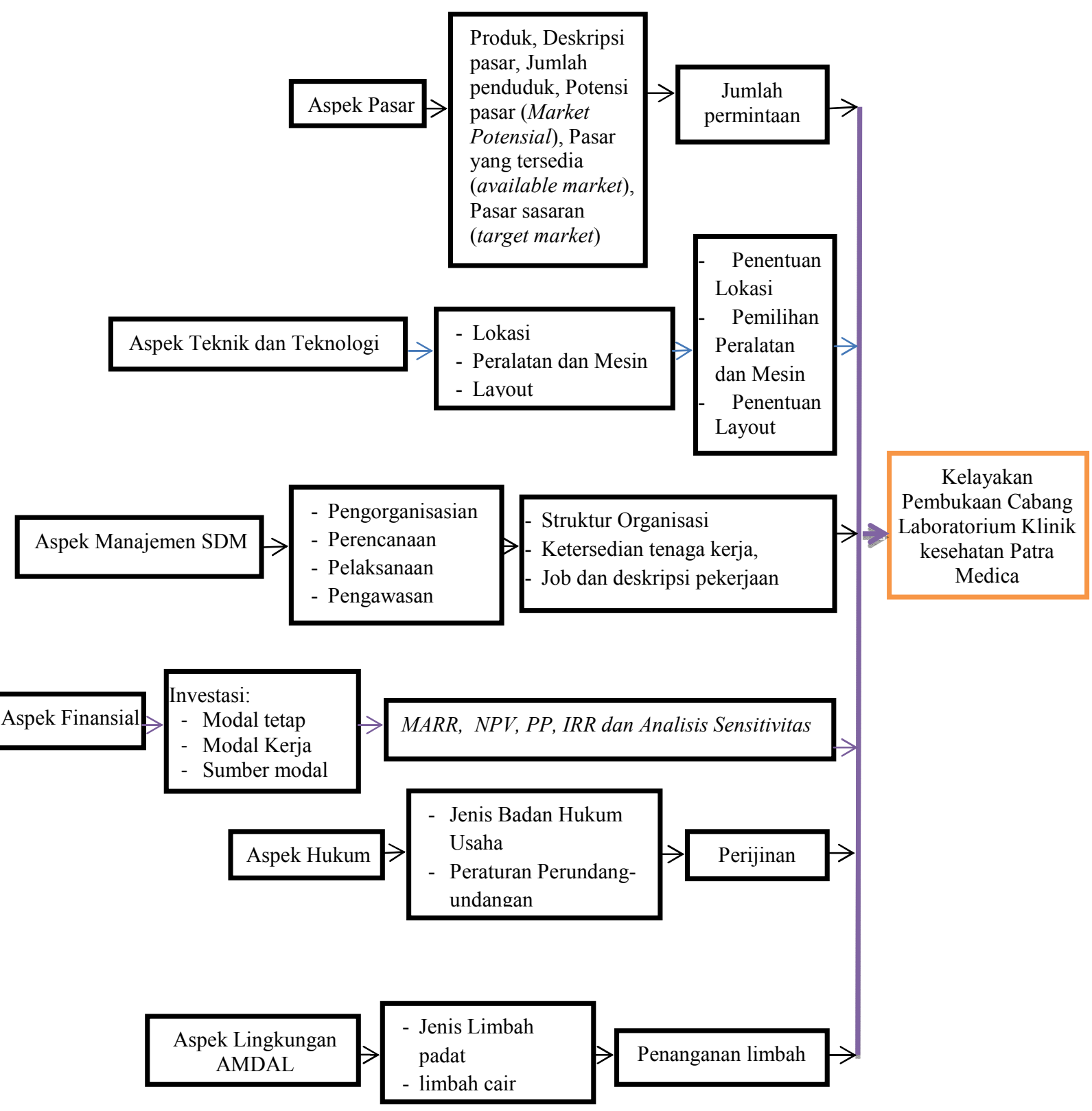

Gambar 1. Kerangka Kerja Penelitian.

penyelenggaraan usaha di Indonesia. AMDAL ini dibuat saat perencanaan suatu proyek yang diperkirakan akan memberikan pengaruh terhadap lingkungan hidup di sekitarnya (Umar, 2001).

Diagram diatas dapat dijabarkan sebagai berikut. Aspek pasar, deskripsi pasar antara lain daerah atau luas pasar, saluran distribusi atau paraktik perdagangan setempat, besarnya jumlah nilai konsumsi produk barang / jasa yang bersangkutan serta identifikasi konsumen barang atau jasa, analisis penawaran barang atau jasa yang bersangkutan, perkiraan barang atau jasa yang bersangkutan, memperkirakan pangsa pasar (market share), parameter yang digunakan dalam kelayakan ini adalah dari jumlah permintaan yang didapat dari analisa jumlah penduduk, pasar potensial, pasar sasaran, pasar yang tersedia di Kabupaten Boyolali.

Sedangkan dari aspek teknik dan teknologi parameter yang digunakan dalam kelayakan adalah layout / letak tempat usaha akan didirikan, mesin atau alat serta fasilitas yang digunakan dengan cara menganalisa 
wilayah atau lokasi, bangunan dan juga pengadaan perlengkapan yang dibutuhkan dalam menunjang pendirian laboratorium klinik kesehatan.

Selanjutnya pada aspek manajemen dan sumberdaya manusia, pada aspek ini kaitannya dengan manajemen organisasi, perencanaan, pelaksanaan dan pengawasan dimana parameter kelayakan yang digunakan yaitu parameter dari struktural organisasi, ketersediaan tenaga kerja serta job dan deskripsi pekerjaan yang diterapkan dalam laboratorium klinik kesehatan tersebut.

Di lanjutkan pada aspek fianansial, pada aspek finansial berkaitan dengan jumlah investasi modal tetap, modal kerja, sumber modal yang dibutuhkan dan prosedur pengambilan keputusan, dimana besarnya laba / profit Minimum Attractive Rate of Return (MARR ), NPV (Net Present Value), PP (Payback Period) dan Analisis sensitifivas. Dari hasil kegiatan usaha tersebut dijadikan sebagai parameter kelayakan dalam hal investasi.

Sedang pada aspek hukum, aspek hukum hal yang dikaji yaitu mengenai peraturan - peraturan pemerintah maupun undang - undang bidang usaha yang berkaitan dengan laboratorium klinik kesehatan dimana parameter kelayakannya yaitu pada penerapan ijin / perijinan atau aturan aturan yang harus dijalankan pada usaha laboratorium klinik kesehatan tersebut.

Untuk aspek lingkungan, analisis dampak lingkungan (AMDAL) dimana dalam proses kegiatan usaha laboratorium ini nantinya menghasilkan limbah sisa laboratorium yang bisa mengakibatkan pencemaran lingkungan, maka dari itu parameter kelayakan yang digunakan yaitu bagaimana proses pengelolaan atau penanganan limbah tersebut agar tidak mencemari lingkungan.

\section{HASIL DAN PEMBAHASAN \\ 4.1. Aspek Pasar}

Hasil pengolahan data dari aspek pasar yaitu meliputi :

\section{a. Potensi Pasar (Market Potensial)}

Pasar Potensial Laboratorium Kesehatan. Dari data yang ada terdapat 79,2 $\%$ atau sejumlah 769.266 masyarakat Kabupaten Boyolali yang memenuhi syarat PHBS. Jumlah 79,2\% tersebut merupakan pasar potensial dari Laboratorium Kesehatan Patra Medica.

\section{b. Pasar yang Tersedia (Available Market)}

Dalam mengkaji pasar yang tersedia untuk laboratorium klinik kesehatan yaitu berkaitan dengan masyarakat Kabupaten Boyolali yang memenuhi syarat PHBS dan memiliki BPJS, yaitu sejumlah 206.611 jiwa atau sebanyak 21,2\%, dan laboratorium Patra Medica Pusat telah bekerja sama dengan BPJS.

\section{c. Pasar Sasaran (Target Market)}

Besarnya pasar sasaran akan ditentukan oleh manajemen dengan mempertimbangkan analisis SWOT.

\section{- Analisis SWOT}

Adapun yang menjadi alasan penentuan strategi - strategi SWOT diatas. Keterangan prioritas penentuan strateginya adalah :

1. Strategi SO

a) Menjaga kualitas produk pelayanan.

b) Menambah jenis paket pelayanan lainnya.

2. Strategi ST

a) Menjaga ciri khas pelayanan laboratorium.

b) Menjaga kualitas peralatan dan perlengkapan.

3. Strategi WO

a) Perhatian pemerintah.

b) Meningkatkan promosi.

4. Strategi WT

a) Motivasi pelaku usaha. 
Tabel 1. Jumlah Pasar Dalam Prosentase

\begin{tabular}{cc}
\hline Pasar & Presentase \\
\hline - Pasar potensial & $-79,2 \%$ dari Jumlah Penduduk \\
- Pasar tersedia & $-21,2 \%$ dari Jumlah Penduduk \\
- Pasar sasaran & $-8 \%$ dari Pasar Tersedia \\
\hline
\end{tabular}

Tabel 2. Proyeksi Jumlah Permintaan

\begin{tabular}{|c|c|c|c|c|c|}
\hline \multirow{2}{*}{ Analisa } & \multicolumn{5}{|c|}{ Tahun } \\
\hline & 2018 & 2019 & 2020 & 2021 & 2022 \\
\hline $\begin{array}{l}\text { 1. Proyeksi Jumlah } \\
\text { Penduduk }\end{array}$ & 981532 & 985189 & 988846 & 992504 & 996161 \\
\hline 2. Pasar potensial & 777373 & 780270 & 783166 & 786063 & 788960 \\
\hline 3. Pasar tersedia & 208085 & 208860 & 209635 & 210411 & 211186 \\
\hline 4. Pasar sasaran & 16647 & 16709 & 16771 & 16833 & 16895 \\
\hline $\begin{array}{l}\text { 5. Jumlah Permintaan / } \\
\text { hari }\end{array}$ & 59 & 59 & 59 & 60 & 60 \\
\hline
\end{tabular}

Tabel 3. Rincian Jumlah Permintaan (Pasien)

\begin{tabular}{|c|c|c|c|c|c|}
\hline \multirow{2}{*}{ Jenis Pemeriksaan } & \multicolumn{5}{|c|}{ Tahun } \\
\hline & 2018 & 2019 & 2020 & 2021 & 2022 \\
\hline $\begin{array}{c}\text { Cek Darah } \\
\text { (62\% Pasar Sasaran) }\end{array}$ & 10321 & 10360 & 10398 & 10436 & 10475 \\
\hline $\begin{array}{c}\text { Paket A } \\
\text { (10\% Pasar Sasaran) }\end{array}$ & 1665 & 1671 & 1677 & 1683 & 1690 \\
\hline $\begin{array}{c}\text { Paket B } \\
\text { (2\% Pasar Sasaran) }\end{array}$ & 333 & 334 & 335 & 337 & 338 \\
\hline $\begin{array}{c}\text { Paket C } \\
\text { (1\% Pasar Sasaran) }\end{array}$ & 166 & 167 & 168 & 168 & 169 \\
\hline $\begin{array}{c}\text { Paket Medical Check Up } \\
\text { Biasa } \\
(20 \% \text { Pasar Sasaran })\end{array}$ & 3329 & 3342 & 3354 & 3367 & 3379 \\
\hline $\begin{array}{c}\text { Paket Medical Check Up } \\
\text { Sedang } \\
\text { (2\% Pasar Sasaran) }\end{array}$ & 333 & 334 & 335 & 337 & 338 \\
\hline $\begin{array}{c}\text { Paket Medical Check Up } \\
\text { Eksekutif } \\
\text { (3\% Pasar Sasaran) }\end{array}$ & 499 & 501 & 503 & 505 & 507 \\
\hline Total Jumlah Permintaan & 16647 & 16709 & 16771 & 16833 & 16895 \\
\hline
\end{tabular}

Besarnya pasar sasaran yang diambil sebesar 8\% tidak lepas dari Analisa secara kualitatif yaitu Analisis SWOT, meliputi kekuatan (strengths), kelemahan (weaknesses), peluang (opportunities) dan Ancaman (threats), dari laboratorium yang dijadikan target pasar dari usaha ini rata rata sejumlah 16.771 konsumen pertahunnya, jumlah tersebut merupakan target pasar yang cukup besar bagi laboratorium kesehatan.

\subsection{Analisis Aspek Teknis dan Teknologi}

Analisis aspek teknis dan teknologi membahas tentang lokasi kegiatan usaha, lay out Laboratorium klinik Kesehatan Patra Medica dan pemilihan jenis teknologi dan peralatan. Aspek teknis dan teknologi dalam 
Tabel 4. Sebaran Sarana Kesehatan

\begin{tabular}{|c|c|c|c|c|c|c|c|c|c|}
\hline $\begin{array}{c}\text { Faktor } \\
\text { penyebaran } \\
\text { sarana } \\
\text { kesehatan } \\
\text { Kecamatan / } \\
\text { Subdistrict }\end{array}$ & RSU & $\begin{array}{c}\text { RS } \\
\text { Swasta }\end{array}$ & $\begin{array}{c}\text { Rumah } \\
\text { Bersalin } \\
\text { (RB) }\end{array}$ & $\begin{array}{c}\text { Poliklinik } \\
\text { Swasta } \\
\text { (Labkes) }\end{array}$ & $\begin{array}{l}\text { Pus } \\
\text { Kes } \\
\text { mas }\end{array}$ & $\begin{array}{c}\text { Pus } \\
\text { Kes } \\
\text { mas } \\
\text { Perawatan }\end{array}$ & $\begin{array}{c}\text { Pus } \\
\text { Kes } \\
\text { mas } \\
\text { Pembantu }\end{array}$ & $\begin{array}{c}\text { Tempat } \\
\text { Praktek } \\
\text { Dokter }\end{array}$ & $\begin{array}{c}\text { Tempat } \\
\text { Praktek } \\
\text { Dokter } \\
\text { Gigi }\end{array}$ \\
\hline 1 Boyolali & 1 & 4 & 1 & 4 & 3 & - & 2 & 174 & 13 \\
\hline 2 Banyudono & 1 & 1 & 1 & 1 & 2 & - & 1 & 37 & 6 \\
\hline 3 Mojosongo & - & 1 & 1 & - & 1 & - & 3 & 26 & 3 \\
\hline 4 Ampel & - & - & - & - & 2 & 1 & 2 & 14 & 2 \\
\hline 5 Teras & - & - & - & - & 1 & - & 3 & 14 & 2 \\
\hline
\end{tabular}

kelayakan usaha Laboratorium klinik Patra Medica secara teknis dan pengoperasiannya dikategorikan layak jika mampu dalam melayani permintaan pasar.

\subsection{Lokasi Usaha}

Ada beberapa faktor yang perlu di pertimbangkan dalam menentukan lokasi usaha, diantaranya :

1. Faktor kepadatan penduduk dan Geografi

Dimana ada tiga kecamatan yang memiliki jumlah penduduk terbanyak di Kabupaten Boyolali dengan berurutan meliputi Kecamatan Ngemplak sejumlah 74.203 jiwa, Kecamatan Ampel sejumlah 70.772 jiwa Kecamatan Nogosarai sejumlah 62.501 Jiwa.

Sedangkan secara geografis untuk pemilihan tempat yang strategis dan mudah dijangkau bagi konsumen / pasien, maka ditentukan daerah atau kecamatan yang secara geografi kecamatan tersebut dilintasi jalan utama atau jalan raya nasional, kecamatan kecamatan yang dilintasi jalan utama atau jalan propinsi (Jalan Raya Boyolali - Semarang) yaitu meliputi Kecamatan Banyudono, Kecamatan Teras, Kecamatan Mojosongo, Kecamatan Boyolali dan Kecamatan Ampel.

2. Sebaran Sebaran Sarana Kesehatan

Dari lima kecamatan yang dilintasi jalan raya utama / propinsi yaitu jalan BoyolaliSemarang, dimana jumlah sarana kesehatan dengan urutan terbanyak yaitu seperti tabel 4.

\section{Faktor Jumlah Competitor}

Jumlah klinik dan pelayanan sejenis laboratorium yang terdata dalam dinas kesehatan Kabupaten Boyolali adalah sejumlah 18 unit.

4. Faktor harga sewa atau beli bangunan

Untuk Harga sewa di sepanjang jalan utama propinsi dan dekat dengan fasilitas public seperti SPBU, Bank, Sekolahan, Pasar dan lain - lain, baik itu di Kecamatan Banyudono, Kecamatan Teras, Kec. Boyolali, Kecamatan Mojosongo dan Kecamatan Ampel harganya hampir relatif sama yaitu rata - rata untuk luas tanah 228 $m^{2}$ dan luas bangunan $168 m^{2} \pm$ Rp.60.000.000 - Rp. 80.000.000 / Tahun.

5. Faktor Perijinan

Faktor perijinan yaitu berkaitan dengan aturan yang berlaku dalam mendirikan lokasi usaha, untuk jenis laboratorium klinik kesehatan lokasi usaha penyebarannya ditentukan oleh Pemerintah Kota / Kabupaten, dalam penelitian ini adalah Pemerintahan Kabupaten Boyolali.

Dari kelima faktor diatas, maka dipilih kecamatan dengan kepadatan penduduk yang tinggi, secara geografis juga dilalui jalur utama / jalan propinsi (Jl. BoyolaliSemarang), memiliki sedikit sarana kesehatan dan juga competitor serta harga sewa relatif murah, maka pemilihan ditentukan di Kecamatan Ampel. Dimana kecamatan tersebut dengan jumlah penduduk cukup tinggi dan secara geografis juga 
Tabel 5. Mesin dan Peralatan

\begin{tabular}{|c|c|c|c|}
\hline No & Jenis & Nama Mesin & Spesifikasi \\
\hline 1 & $\begin{array}{l}\text { Alat pemeriksaan } \\
\text { Kimia menggunakan }\end{array}$ & $T R X 7010$ & $\begin{array}{l}\text { Spesifikasi : Full Automatic, Made in } \\
\text { Japan, Kecepatan } 240 \text { tes / jam, } \\
\text { dilengkapi dengan Lavelly Jannings }\end{array}$ \\
\hline & $\begin{array}{l}\text { alat Full } \\
\text { Automatomatic }\end{array}$ & RESPON 910 & $\begin{array}{l}\text { Spesifikasi : Full Automatic,Made in } \\
\text { Jerman,Kecepatan } 160 \text { tes / jam }\end{array}$ \\
\hline 2 & $\begin{array}{l}\text { Alat Pemeriksaan } \\
\text { Hematologi Analyzer }\end{array}$ & ABX MICROS 60 & $\begin{array}{l}\text { Spesifikasi : Semi Automatic, Made in } \\
\text { Prancis, Kecepatan } 60 \text { tes / jam }\end{array}$ \\
\hline 3 & $\begin{array}{l}\text { Alat Pem } \\
\text { Imun }\end{array}$ & MINIVIDAS & $\begin{array}{l}\text { Untuk Pemeriksaan : TORCH } \\
\text { (Toxoplasma, Rubella, CMV, HSV, } \\
\text { Chlamydia, Hormon Thyroid ( } \mathrm{T} 3, \mathrm{~T} 4 \text {, } \\
\text { TSH, dll), Tumor Marker ( Ca 19-9, Ca } \\
\text { 125, dll), HbsAg Titer, Anti HbsAg Titer }\end{array}$ \\
\hline 4 & $\begin{array}{l}\text { Pemeriksaan } E C G \\
\text { langsung dengan } \\
\text { intepretasi hasil }\end{array}$ & CARDIOCARE & $\begin{array}{l}\text { Spesifikasi : } 12 \text { Channel, Made in Korea } \\
\text { Sudah dengan Inteprestasi hasil }\end{array}$ \\
\hline 5 & Mesin USG 4D & MINDRAY DC & Sudah deng \\
\hline 6 & Rontgen & Medica YZ $100 \mathrm{~mA}$ & Kelangkapan Kamar gelap \\
\hline 7 & Rontgen in Car & $\begin{array}{l}\text { Medica YZ } 100 \mathrm{~mA} \\
\text { (Mitsubishi Travel) }\end{array}$ & Unit Mobil Rontgen set \\
\hline 8 & Treadmill & Treadmill b612 & Digital windows $X P$ \\
\hline 9 & $\begin{array}{c}\text { Pemeriksaan Microba } \\
\text { Manual }\end{array}$ & Microscope & Pemeriksaan Manual \\
\hline 10 & Paket THT & GM-10071 & Jenis : Diagnostic set \\
\hline
\end{tabular}

dilintasi jalan raya utama serta memiliki sarana kesahatan dengan jumlah yang relatif sedikit.

\subsection{Teknologi dan Peralatan}

Jenis Teknologi dan peralatan yang digunakan terdapat pada tabel 5. Mesinmesin diatas dalam pengoperasiannya sangat mampu untuk melayani pasien

\subsection{Layout}

Layout tata ruang gedung Laboratorium Klinik kesehatan Patra Medica menggunakan gedung dua lantai dengan ruanganannya terdapat pada gambar 2 . Luas bangunan lantai dasar seluas $168 \mathrm{~m}^{2}$ dan lantai atas seluas $84 \mathrm{~m}^{2}$ ditambah area parkir seluas $60 \mathrm{~m}^{2}$. dengan jumlah rata-rata perharinya 75 pasien dengan jam kerja 14 jam atau sama dengan 5 sampai 6 orang tiap jamnya.

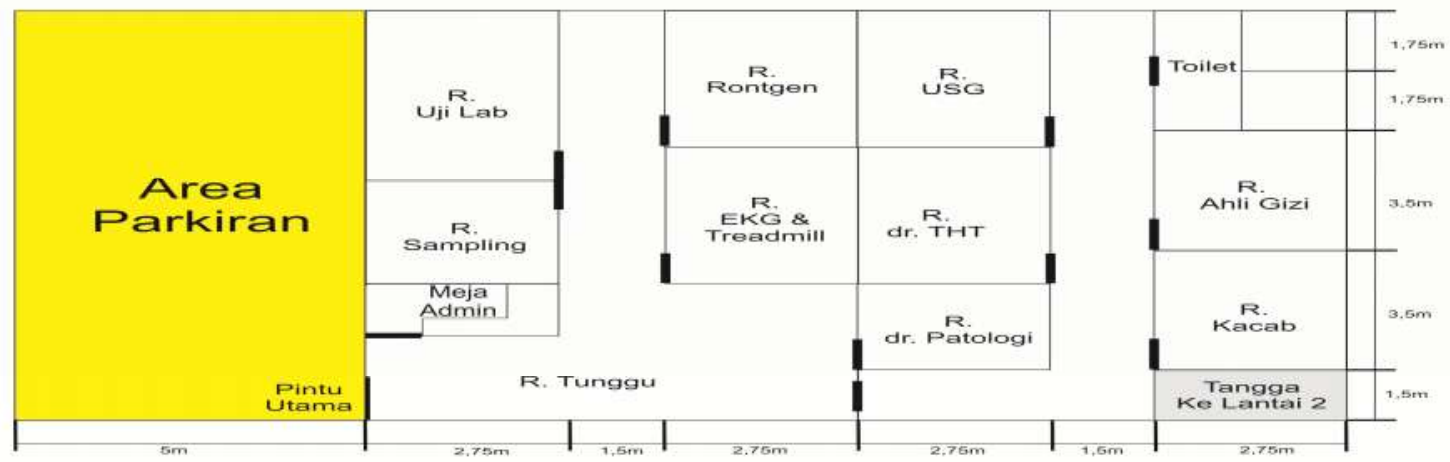

Gambar 2. Layout Gedung Lantai Dasar dan Tata Ruang. 
Tabel 7. Jumlah Tenaga Kerja (Sumber : Pengolahan Data)

\begin{tabular}{|c|c|c|c|}
\hline NO & Jabatan & Jumlah & Pendidikan \\
\hline 1 & $\begin{array}{l}\text { Dokter Spesialist Patologi } \\
\text { Klinik }\end{array}$ & 1 & $\mathrm{~S} 1+$ Spesialis \\
\hline 2 & Dokter Spesialist THT & 2 & $\mathrm{~S} 1+$ Spesialis \\
\hline 3 & Ahli Gizi & 1 & S1 (Gizi) \\
\hline 4 & Kepala Cabang & 1 & S1 (Kesmas) \\
\hline 5 & Rontgen & 3 & D3 (Amd.TRO) \\
\hline 6 & Marketing & 5 & S1 (Marketing) \\
\hline 7 & Analis & 6 & S1 / SMA Analis \\
\hline 8 & Perawat & 6 & D3 Perawat \\
\hline 9 & Administrasi & 2 & D3 \\
\hline 10 & OfFice Boy & 3 & SMA \\
\hline \multicolumn{2}{|r|}{ Total } & 30 & \\
\hline
\end{tabular}

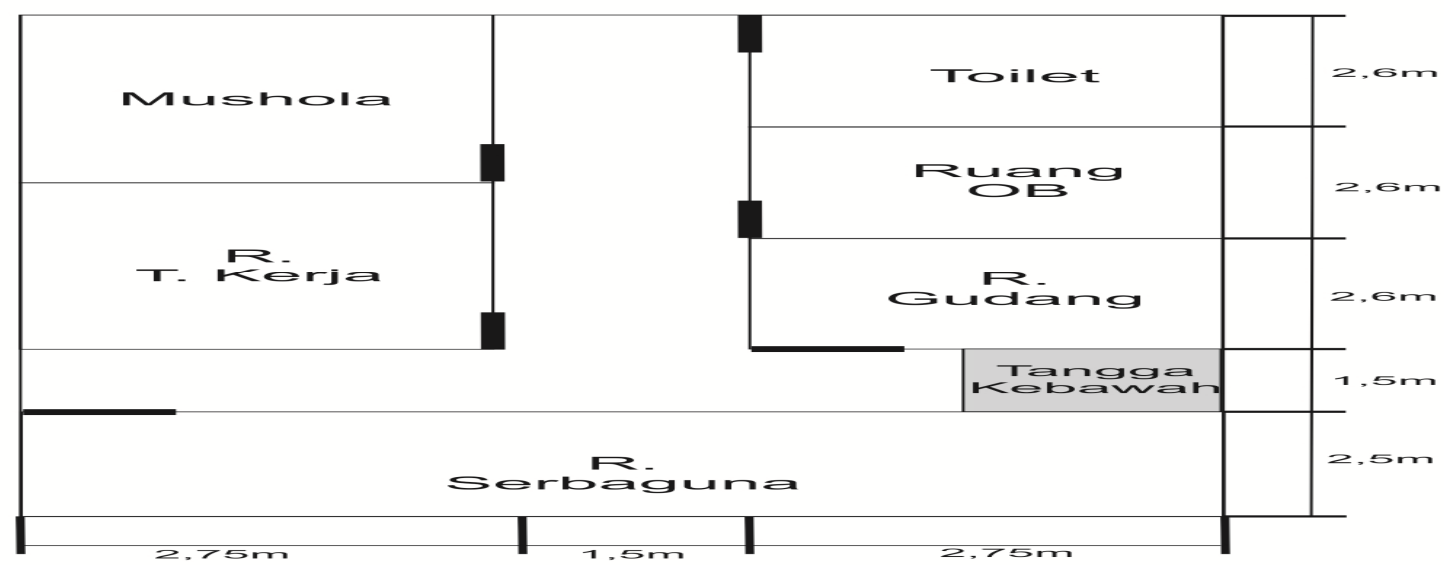

Gambar 3. Layout Gedung Lantai Dua dan Tata Ruang.

Dengan menawarkan kemudahan bagi konsumen dalam menjangkau lokasi usaha, dan kemampuan yang terpercaya dari jenis mesin dan peralatan yang digunakan dalam melayani konsumen, serta layout tata ruang yang memberikan kenyamanan bagi tenaga kerja saat beraktifitas dan kenyamanan pada konsumen saat melakukan kontrol kesehatan, ini nantinya akan menjadikan nilai tambah tersendiri bagi usaha tersebut dalam memenuhi kebutuhan masyarakat akan sarana kesehatan berupa laboratorium kesehatan.

\subsection{Aspek Manajemen}

\subsubsection{Perencanaan (Planning)}

Dari perencanaan terdapat gambaran tentang prospek atau kemungkinankemungkinan dari usaha yang akan dijalankan diantaranya adalah adanya permintaan terhadap jasa kesehatan, tersedianya peralatan dan perlengkapan dengan harga terjangkau, tersedianya tenaga kerja dan fasilitas pendukung, adanya peluang untuk mendirikan usaha laboratorium kesehatan dengan kapasitas dan biaya yang memadai, estimasi keuntungan sehingga perusahaan dapat bertahan dan berkembang.

\subsubsection{Pengorganisasian (Organizing)}

Dalam pengorganisasian dapat tertata dengan jelas antara tugas, wewenang, dan tanggung jawab serta hubungan kerja dengan sebaik mungkin dalam bidangnya masing - masing. Dari analisis kebutuhan tenaga kerja yang telah dilakukan dalam aspek teknik dan teknologi, dan aspek 
manajemen tersebut maka akan dapat diketahui.

1. Jumlah Tenaga Kerja dan Kualifikasi Jumlah tenaga kerja yang dibutuhkan sesuai kapasitas perusahaan, Karena Laboratorium Klinik Patra Medica menggunakan sistem 2 shift maka pembagian tenaga kerjanya seperti pada tabel 7.

2. Tugas dan wewenang serta tanggung jawab dari setiap tenaga kerja.

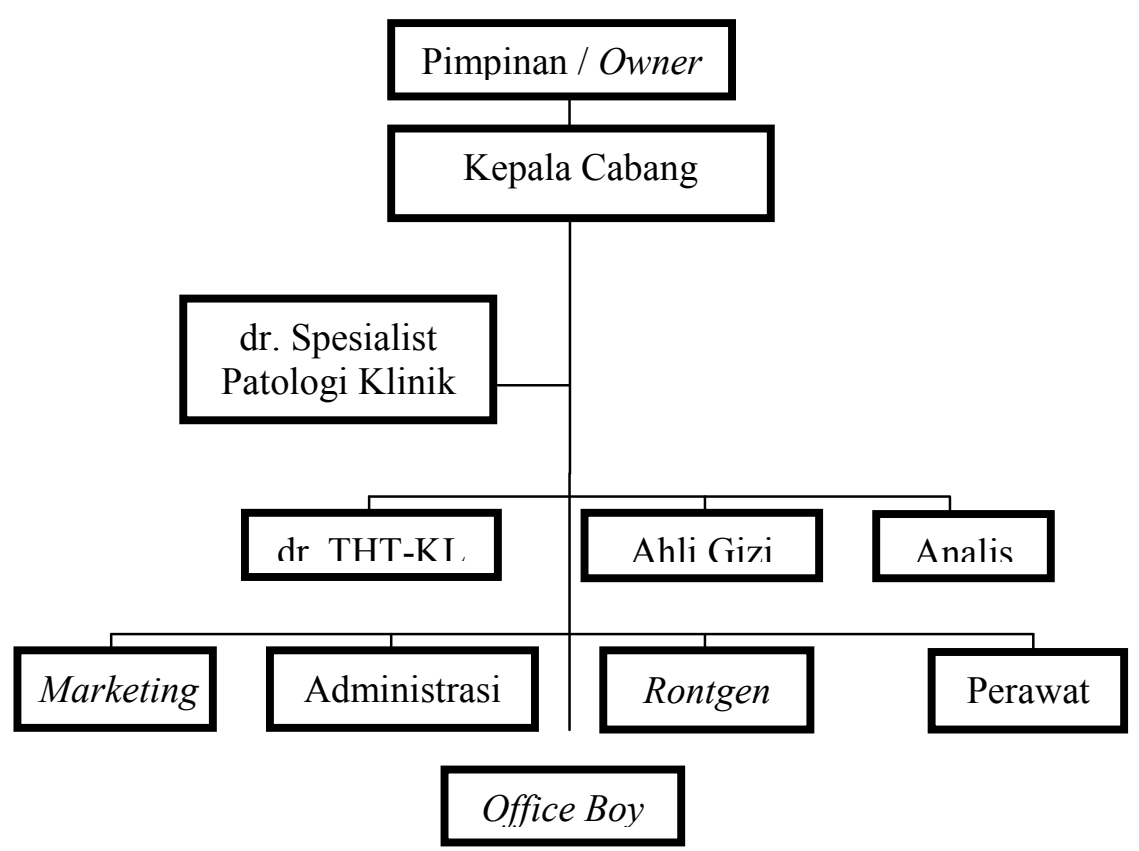

Gambar 4. Struktur Organisasi Laboratorium Klinik Kesehatan Patra Medica.

Adapun tugas dan wewenangnya serta tanggung jawabnya Sumber Daya di Laboratorium Klinik Kesehatan Patra Medica meliputi :

1. Pimpinan / Owner, Pimpinan sekaligus owner, merupakan pemilik laboratorium yang bertanggung jawab terhadap izin usaha dan permodalan Laboratorium klinik Patra Medica.

2. Kepala Cabang, Merupakan pengelola cabang yang bertanggung jawab terhadap seluruh kegiatan laboratorium dicabang yang dipimpin.

3. Office Boy, Mempunyai tanggung jawab terhadap kebersihan dan perawatan area laboratorium, disini $O B$ juga sebagai kurir pengantar hasil Laboratorium kepada pasien.

4. Administrasi, Pegawai administrasi bertugas memasukan data keuangan, data kebutuhan lab maupun data pasien untuk memperlancar jalannya proses pelayanan uji laboratorium.

5. Marketting, memiliki tugas dan tanggung jawab dalam hal pemasaran maupun periklanan, dengan tujuan agar masyarakat mengenal atau mengetahui adanya laboratorium Patra Medica serta menjalin komunikasi dengan dokterdokter spesialis yang ada di Kecamatan Boyolali khususnya dan Kabupaten Boyolali pada umumnya.

6. Dokter spesialis atau dokter patologi memiliki tugas :

a. Melaksanakan kegiatan teknis dan pembinaan tenaga analis kesehatan sesuai dengan kompetensinya.

b. Mengkoordinir kegiatan pemantapan mutu, pencatatan dan pelaporan.

c. Mengkoordinir dan melaksanakan kegiatan Keamanan dan Keselamatan Kerja laboratorium.

d. Melakukan komunikasi / konsultasi medis dengan tenaga medis lain. 
7. Dokter spesialis THT-KL

Dokter yang memiliki spesialisasi dalam menangani gangguan Spesialis Telinga Hidung Tenggorokan - Kepala dan Leher.

8. Ahli Gizi.

Ahli gizi adalah seorang tenaga kesehatan yang berhubungan dengan gizi yang terdapat dalam makanan.mempunyai tugas dan tanggung jawab dan wewenang secara penuh untuk melakukan kegiatan fungsional dalam bidang pelayanan gizi, dietetik, baik di masyarakat, rumah sakit atau individu.

9. Tenaga Ahli Rontgen

Tugasnya menggunakan sinar-x (sinar Rontgen) untuk membuat gambar Radiografi (gambar Rontgen) yang baik, yang dapat dipergunakan untuk menegakkan diagnosa.

10. Tenaga Analis, memiliki tugas :

a. Melaksanakan kegiatan teknis sesuai standar pelayanan dan standar operasional prosedur.

b. Melaksanakan kegiatan pemantapan mutu, pencatatan dan pelaporan.

c. Melaksanakan kegiatan Keamanan dan Keselamatan Kerja laboratorium.

d. Melakukan konsultasi dengan penanggung jawab teknis laboratorium atau tenaga teknis lain.

11. Perawat pada laboratorium klinik, memiliki tugas :

a. Melakukan tindakan untuk pengambilan spesimen laboratorium.

b. Melakukan pertolongan pertama terhadap pasien.

c. Melaksanakan kegiatan Keamanan dan Keselamatan Kerja (K-3) laboratorium.

d. Melakukan konsultasi dengan penanggung jawab teknis laboratorium atau tenaga teknis lain.

\subsubsection{Pelaksanaan (Actuating)}

Dalam pelaksanaan menjalankan organisasi, pimpinan menggerakkan bawahnnya (para karyawan) untuk mengerjakan pekerjaan yang telah ditentukan dengan cara memimpin, memberi perintah, memberi petunjuk dan memberi motivasi, diantaranya yaitu adanya komunikasi yang baik antar tenaga kerja, penjadwalan rotasi shift, kenaikan gaji dan bonus.

\subsubsection{Pengawasan (Leading)}

Pengawasan dijalankan untuk mengukur dan menilai pelaksanaan tugas apakah telah sesuai dengan rencana. Jika dalam proses tersebut terjadi penyimpangan, maka akan segera dikendalikan. Dalam hal ini untuk pengawasan kinerja tenaga kerja dilakukan oleh kepala cabang, diantaranya pengawasan untuk dapat mencapai target sesuai proyeksi permintaan yang telah dibahas dalam aspek pasar, pengawasan jika terjadi penyimpangan - penyimpangan dalam pemcapaian target baik dari faktor internal seperti penyimpangan tugas wewenang tenaga kerja, penyimpangan terhadap peralatan atau mesin, dan lain sebagainya, serta pengawasan dari faktor eksternal yang berkaitan dengan informasi - informasi dunia kesehatan. Sedangkan untuk pengawasan hasil laboratorium dibawah pengawasan dan tanggung jawab Dokter Patologi. Dengan adanya pengelolaan manajemen tersebut, maka akan menjadikan usaha laboratorium kesehatan Patra Medica dapat maju dan berkembang sesuai tujuan.

\subsection{Aspek Finansial}

Aspek finansial pada penelitian ini meliputi biaya - biaya yang digunakan dalam kegiatan pembangunan usaha yaitu biaya investasi dan biaya yang diperlukan dalam kegiatan operasional, yaitu biaya operasional.

\section{a. Biaya Investasi / Modal}

Biaya Investasi / modal dikeluarkan pada tahun pendirian, dalam penelitian ini tahun pendiriannya yaitu pada tahun 2017, dan dalam pengelolaannya biaya investasi / modal dikelompokan menjadi dua yaitu biaya modal tetap dan biaya modal kerja. 


\section{b. Biaya Modal Tetap}

Tabel. 8. Investasi / Modal Laboratorium Klinik Kesehatan Patra Medica

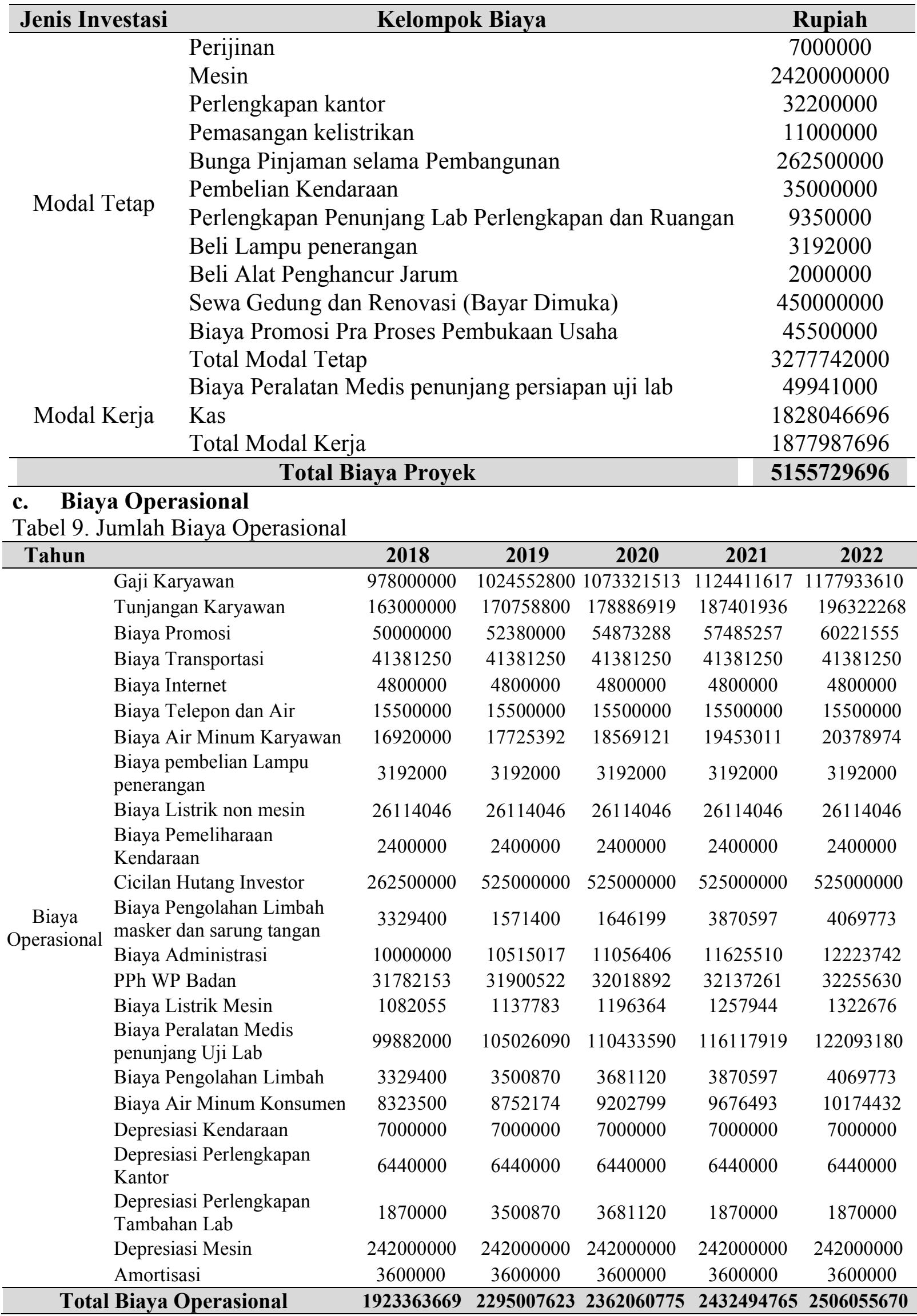




\section{d. Proyeksi Penerimaan}

Tabel 10. Proyeksi Penerimaan Pertahun

\begin{tabular}{|c|c|c|c|c|c|}
\hline \multirow{2}{*}{ Analisa } & \multicolumn{5}{|c|}{ Tahun } \\
\hline & 2018 & 2019 & 2020 & 2021 & 2022 \\
\hline $\begin{array}{l}\text { Jumlah } \\
\text { Permintaan } \\
\text { Pertahun }\end{array}$ & 16647 & 16709 & 16771 & 16833 & 16895 \\
\hline $\begin{array}{ll}\text { Cek } & \text { Darah } \\
(62 \%) & \text { Harga } \\
70.000 & \end{array}$ & 722479800 & 725170600 & 727861400 & 730552200 & 733243000 \\
\hline $\begin{array}{l}\text { PAKET A } \\
(10 \%) \text { Harga } \\
\text { Rp 322.000 }\end{array}$ & 536033400 & 538029800 & 540026200 & 542022600 & 544019000 \\
\hline $\begin{array}{l}\text { PAKET B } \\
(2 \%) \quad \text { Harga } \\
\text { Rp382.000 }\end{array}$ & 127183080 & 127656760 & 128130440 & 128604120 & 129077800 \\
\hline $\begin{array}{l}\text { PAKET C } \\
(1 \%) \quad \text { Harga } \\
\text { Rp 482.000 }\end{array}$ & 80238540 & 80537380 & 80836220 & 81135060 & 81433900 \\
\hline $\begin{array}{lr}\text { Paket } & \\
\text { Medical } \\
\text { Check } \\
\text { Biasa } \\
\text { Harga } & (20 \%) \\
700.000 & \text { Rp } \\
7000\end{array}$ & 2330580000 & 2339260000 & 2347940000 & 2356620000 & 2365300000 \\
\hline $\begin{array}{lr}\text { Paket } & \\
\text { Medical } & \\
\text { Check } & \text { Up } \\
\text { Sedang } & (2 \%) \\
\text { Harga } & \text { Rp } \\
800.000 & \end{array}$ & 266352000 & 267344000 & 268336000 & 269328000 & 270320000 \\
\hline $\begin{array}{l}\text { Paket } \\
\text { Medical } \\
\text { Check Up } \\
\text { Eksekutif } \\
(3 \% \text { Harga } \\
\text { Rp 1000.000 }\end{array}$ & 499410000 & 501270000 & 503130000 & 504990000 & 506850000 \\
\hline $\begin{array}{c}\text { Total } \\
\text { Penerimaan }\end{array}$ & 4562276820 & 4579268540 & 4596260260 & 4613251980 & 4630243700 \\
\hline
\end{tabular}

\section{e. Proyeksi aliran kas (Cash Flow)}

Cash flow dapat memberikan informasi mengenai jumlah kas yang diperlukan dalam memulai suatu usaha, perencanaan investasi, dan menjamin kesesuaian kas untuk ketersediaan kas terhadap pengeluaranpengeluaran yang akan terjadi di masa datang, dimana periode pembangunan atau renovasi gedung dan semua persiapan diasumsikan membutuhkan waktu selama 6 bulan atau setengah tahun maka untuk cicilan hutang dan bunga investor saat pembangunan laboratorium klinik kesehatan patra medika digabung dengan laporan keuangan tahun pertama dimulainya usaha yaitu tahun 2018. Proyeksi aliran Kas diketahui bahwa kas akhir tahun 2018 sebesar Rp. -2.516.816.545, kas akhir tahun 2019 sebesar Rp. -232.555.628, kas akhir tahun 2020 sebesar Rp. 2.001.643.857, kas 
Tabel 11. Perhitungan Sensisitivitas

\begin{tabular}{cccc}
\hline No & Besarnya Penurunan & MARR & NPV \\
\hline 1 & $5 \%$ & $20 \%$ & 1162292708 \\
2 & $10 \%$ & $20 \%$ & 496696386 \\
3 & $12 \%$ & $20 \%$ & 230457858 \\
\hline
\end{tabular}

akhir tahun 2021 sebesar Rp. 4.182.401.072 dan kas akhir tahun 2022 atau pada tahun ke lima sebesar Rp. 6.306.589.102.

\section{f. Minimum Attractive Rate of Return (MARR)}

Dimana nilai MARR harus ditetapkan lebih tinggi dari Cost of Capital. Nilai MARR dalam penelitian ini adalah :

MARR $=\mathrm{Ic}+\% \mathrm{t}$

Dimana :

$$
\begin{aligned}
\mathrm{Ic}= & \text { Cost of Capital } \\
\mathrm{t}= & \text { Tingkat pajak pedapatan kombinasi, } \\
& \text { dalam penelitian ini " } \mathrm{t} \text { " didapat dari } \\
& \text { pajak pendapatan (PPH Wp Badan } \\
& \text { sebesar } 1 \% \text { ), ditambah besarnya resiko } \\
& (\text { ditentukan manajemen sebesar } 10 \%) . \\
\mathrm{t}= & 11 \% .
\end{aligned}
$$

Ic $\quad=$ rd. Id $+(1-$ rd $)$ Ie.

Dimana :

$$
\begin{aligned}
\mathrm{Rd}= & \text { Rasio antara hutang dan modal } \\
& \text { seluruhnya. } \\
1-\mathrm{rd}= & \text { Rasio modal sendiri dan modal } \\
& \text { seluruhnya. } \\
\mathrm{Id}= & \text { Rate of Return dari modal pinjaman. } \\
\mathrm{Ie}= & \text { Tingkat pengembalian untuk modal } \\
& \text { sendiri. }
\end{aligned}
$$

\section{Cost of Capital:}

Dimana dalam pembukaan cabang Laboratorium Klinik Patra Medica untuk investasinya $30 \%$ dibiayai oleh hutang bank dengan bunga sebesar $15 \%$ dan selebihnya modal sendiri dengan asumsi suku bunga Deposito Tahunan yaitu sebesar $6.5 \%$. Maka Cost of Capital nya adalah :

Ic $=(0.30)(0.15)+(1-0.30)(0.065)=9,05 \%$ (Batas Minimum MARR adalah 9,05\%)
MARR $=9,05 \%+11 \%=20 \%$ (discount factor 20\%).

\section{g. Net Present Velue}

Hasil dari perhitungan diketahui nilai $N P V$ dengan MARR 20\% adalah sebesar Rp. 1.827.889.029, (positif) atau NPV lebih besar daripada Nol $(N P V>0)$.

\section{h. Perhitungan Payback Period}

Periode pengembalian untuk investasi pribadi antara lain :

Modal : Rp 5155729696

- Net Cash Flow Tahun 1 Rp.2638913151.

- Net Cash Flow Tahun 2 Rp.2284260917.

- Net Cash Flow Tahun 3 Rp.2234199484.

- Net Cash Flow Tahun 4 Rp.2180757215.

- Net Cash Flow Tahun 5 Rp.2124188030.

\section{Payback Period}

$=1+(5155729696-2638913151) /$ 2284260917.

$=1+1.1018$ Tahun $=2$ Tahun $(0.1018 \times 12$ bulan).

$=2$ Tahun 1 Bulan $+(0.2216 \times 30)$.

$=2$ Tahun 1 Bulan 6,6 Hari (7 Hari).

Dari perhitungan diatas maka diketahui Payback Period atau periode pengembalian dari biaya awal yaitu selama 2 tahun 1 bulan 7 hari.

\section{i. Analisis Sensistivitas}

Hasil perhitungan analisis sensitivitas ini menggunakan MARR 20\% dimana estimasi penurunan pendapatannya adalah $5 \%, 10 \%$ dan $12 \%$, terdapat pada tabel 11 .

Jika permintaan mengalami penurunan sebesar 5\% nilai NPV nya sebesar Rp. 1.162.292.708, (positif) lebih besar daripada Nol $(>0)$. Jika permintaan mengalami penurunan sebesar $10 \%$ nilai $N P V$ nya sebesarRp. 496.696.386, (positif) atau $N P V$ lebih besar daripada Nol $(>0)$. 
Jika permintaan mengalami penurunan sebesar $15 \%$ nilai $N P V$ nya sebesar $\mathrm{Rp}$. 230.457.858, (positif) NPV lebih besar daripada Nol $(>0)$.

\section{j. Perhitungan Internal Rate of Return (IRR)}

Jika permintaan mengalami penurunan sebesar 20\% maka nilai $N P V$ nya adalah sebesar Rp.97.338.594, (positif) NPV lebih besar daripada Nol $(>0)$. Jika permintaan mengalami penurunan sebesar 26\% maka nilai $N P V$ nya adalah sebesar $\mathrm{Rp} .35 .780 .671$, (negatif) atau $N P V$ lebih kecil daripada Nol $(<0)$.

Dari perhitungan diatas dan dengan menggunakan interpolasi maka didapatkan nilai IRR dari proyek Laboratorium Klinik Kesehatan Patra Medica yaitu :

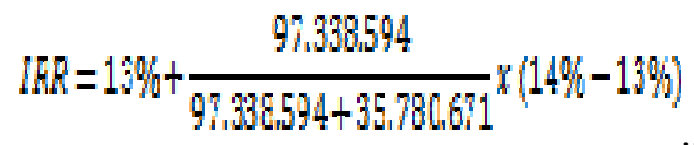

Dari perhitungan interpolasi maka didapat nilai $I R R=13,731 \%$ atau saat terjadi penurunan permintaan sebesar $13,731 \%$, maka $N P V=0$.

Dari uraian pembahasan diatas dimana nilai Minimum Attractive Rate of Return (MARR), NPV, Payback Period, analisis sensitivitas, IRR, menunjukkan bahwa hasil dari pengelolaan dana atau modal dalam pembukaan cabang laboratorium kesehatan menghasilkan keuntungan yang signifikan, sehingga sangat tepat jika investor memberikan modal untuk investasi dalam proses mendirikan sarana kesehatan berupa laboratorium kesehatan di Kabupaten Boyolali.

\subsection{Aspek Hukum}

Aspek hukum yang dipakai yaitu meliputi persyaratan dan perizinan dan legalitas, syarat dan izin penyelenggaraan labratorium klinik nantinya akan dievalusi setiap tahun, dan dalam proses pembukaan usaha Laboratorium Klinik Kesehatan Patra Medica. Sesuai Permenkes Republik Indonesia No. 411 / Menkes / Per / III / 2010 tentang Laboratorium Klinik Kesehatan, dan
Perda Kabupaten Boyolali No 2 Tahun 2012 Tentang Perizinan dan Non Perizinan Bidang Kesehatan.

Semua ketetapan peraturan hukum yang menjadi syarat dalam mendirikan dan mengoperasikan Laboratorium Klinik Kesehatan Patra Medica tersebut dapat terpenuhi. Dimana nantinya izin penyelenggaraan tersebut ditunjukkan kepada Kepala Dinas Kesehatan Kabupaten Boyolali atas rekomendasi ke Kepala Dinas Kesehatan Provinsi Jawa Tengah, Sehingga Laboratorium Kesehatan Patra Medica dalam pendirian dan proses usaha terjamin legailtasnya.

\subsection{Aspek Lingkungan}

Pada aspek Lingkungan, Analisa Dampak Lingkungan (AMDAL) sangat perlu, sesuai isi bab 1 dan lampiran II peraturan menteri lingkungan hidup Republik Indonesia Nomor 08 Tahun 2013 tentang "Tata laksana penilaian dan pemeriksaan dokumen lingkungan hidup serta penerbitan izin lingkungan" dan "Undang-undang Republik Indonesia Nomor 32 Tahun 2009 Tentang perlindungan dan pengelolaan lingkungan hidup".

Dengan mempertimbangkan status tempat (gedung) yaitu sewa 5 tahunan, maka untuk seluruh limbah medis diolah oleh pihak ketiga. Sementara jarum suntik dihancurkan dengan needle destroyer kemudian dilimpahkan ke pihak ketiga juga.

Dengan demikian sisa proses laboratorium tetap terkendali baik untuk waktu jangka pendek maupun untuk waktu jangka panjang, sehingga lingkungan area laboratorium tidak terganggu adanya usaha pendirian cabang Laboratorium Klinik Kesehatan Patra Medica.

\section{KESIMPULAN DAN SARAN}

\subsection{Kesimpulan}

Berdasarkan hasil pengolahan data dan analisa data yang telah dilakukan, maka dapat ditarik kesimpulan :

1. Aspek pasar dari Laboratorium Klinik Kesehatan Patra Medica memiliki prospek yang cukup besar dan masih 
terbuka potensinya, dimana jumlah permintaan rata - rata 60 orang perhari layak untuk diimplementasikan.

2. Dilihat dari analisa aspek teknis dan teknologi menunjukkan bahwa secara kemampuan teknis dan teknologi Laboratorium Klinik Kesehatan Patra Medica ditinjau dari lokasi, layout dan teknologi sangat kompetitif dalam memenuhi permintaan pasar sehingga proyek pembukaan cabang Laboratorium Klinik Kesehatan Patra Medica ditinjau dari aspek teknis dan teknologi layak untuk diimplementasikan.

3. Dari aspek manajemen, dengan diketahui adanya permintaan, tersedianya peralatan dan mesin yang terjangkau sesuai kebutuhan serta tenaga kerja yang sesuai kualifikasi, masih adanya peluang usaha laboratorium dan motivasi kerja sesuai tujuan menjadikan pembukaan cabang Laboratorium Klinik Kesehatan Patra Medica di Kabupaten Boyolali layak untuk diimplementasikan.

4. Berdasarkan analisa finansial yang telah dilakukan dapat diambil kesimpulan sebagai berikut :

a. Dari perhitungan rugi laba, setiap tahun usaha ini akan menghasilkan keuntungan yang terus meningkat.

b. Dari hasil perhitungan parameter kelayakan menunjukkan hasil sebagai berikut :

- MARR : 20\%.

- NPV : > 0 (usaha ini layak untuk diimplementasikan).

- PP: 2 Tahun 1 Bulan 7 Hari dari perencanaan usaha minimal 5 Tahun.

- IRR : Dari perhitungan interpolasi didapat nilai IRR sebesar $13,731 \%$.

Dengan demikian dari segi MARR, NPV, PP, Analisis Sensitifitas dan IRR, menunjukan angka positif, sehingga rencana Laboratorium Klinik Kesehatan ini layak untuk diimplementasikan atau dilanjutkan.
5. Berdasarkan hasil analisa sensitivitas, Jika terjadi perubahan penurunan terhadap pendapatan sebesar 5\% sampai $13,731 \%$, usaha ini masih layak untuk diimplementasikan namun jika Perubahan terhadap pendapatan mengalami penurunan lebih besar dari $13,731 \%$, usaha ini tidak layak untuk diimplementasikan karena akan mengalami kerugian.

6. Berdasarkan analisa aspek hukum dengan dapat dilaksanakan dan dilengkapinya dokumen - dokumen perijinan (legalitas) sesui aturan perundan-undangan yang berlaku maka ditinjau dari aspek hukum mampu untuk emenuhi persyaratan - persyaratan tersebut sehingga layak untuk diimplementasikan atau dilanjutkan.

7. Sedangkan berdasarkan analisa aspek lingkungan (berkaitan dengan AMDAL), pada usaha ini karena pengolahan limbah medisnya di serahkan pada pihak ketiga yaitu perusahaan khusus pengolah limbah medis, dengan demikian tidak terjadi adanya resiko pencemaran lingkungan, sehingga ditinjau dari aspek lingkungan dapat terpenuhi persyaratann dalam pendirian laboratorium klinik kesehatan patra medica serta layak untuk diimplementasikan.

Dari hasil analisa ke tujuh aspek diatas diketahui bahwa, keseluruhan aspek dalam rencana pendirian cabang baru Laboratorium Klinik Kesehatan Patra Medica di Kabupaten Boyolali layak untuk diimplementasikan.

\subsection{Saran}

Perlu adanya penelitian lebih lanjut karena nilai investasi untuk rencana ekspansi ini cukup besar, dan juga perlu adanya keseriusan dalam penanganannya. Perlu penambahan analisa aspek lagi yang memungkinkan akan menambah hasil yang lebih baik lagi dalam penelitian berikutnya. 


\section{DAFTAR PUSTAKA}

Badan Pusat Statistik., 2014. Suku Bunga Kredit Investasi Bank Umum Periode 2010- 2014. (Jakarta).

Badan Pusat Statistik., 2014. Industri Kecil dan Kerajinan Rumah Tangga (IKKR).Jakarta.

Bank Indonesia. Laju Inflasi Nasional Periode 2010-2014.www.go.id.htm, Jakarta.

Djoni Rolindrawan., 2015. The Impact of BPJS Health Implementation for the Poor and Near Poor on the Use of Health Facility.Faculty of Economy and Business - University of Brawijaya, Indonesia.

Handaru dan Tamjudin., 2014. Studi kelayakan bisnis. Edisi 2, penerbit Uniersitas Terbuka.

Hasibuan., 2010. Manajemen Sumberdaya Manusia. Bumi Aksara. Jakarta.

Heizer, Jay dan Barry Render., 2009. Manajemen Operasi Buku 1 Edisi 9.Salemba 4. Jakarta.

Husnan, Suad dan Suwarsono, Mohammad., 2000. Studi Kelayakan Proyek. Edisi Ketiga. Cetakan Pertama. Yogyakarta : Penerbit Unit Penerbit dan Pencetakan.

Jumingan., 2006. Analisis Laporan Keuangan. Jakarta: PT. Bumi Aksara.

Kotler, Philip., 1997. Manajemen Pemasaran : Analisis Perencanaan, Implementasi, dan Kontrol, Ed rev Jilid 1 (Jakarta : Prenhallindo).
Kotler, Philip \& AB Susanto., 1999. Manajemen Pemasaran di Indonesia :Analisis, perencanaan, implikasi dan pengendalian, Buku satu ,Salemba, Jakarta.

Kasmir \& Jakfar., 2007. Studi Kelayakan Bisnis. Kencana Jakarta.

Martiningtyas, N., 2004. Buku Materi Kuliah STIKOM Statistika, STIKOM Surabaya, Surabaya.

Rangkuti, Freddy., 2004. Manajemen Persediaan : Aplikasi di Bidang Bisnis, Grafindo Persada, Jakarta.

Soeharto, Imam., 2002. Studi Kelayakan Proyek Industri .Erlangga, Jakarta.

Sugiyono., 2012. Memahami Penelitian kualitatif. ALFABETA. Bandung.

Suratman., 2001. Studi Kelayakan Proyek (Teknik dan Prosedur Penyusunan Laporan), J \& J Learning, Yogyakarta.

Sutojo, Siswanto., 2000. Studi Kelayakan Proyek : Konsep, Teknik, dan Kasus. Edisi Baru. Jakarta : Damar Mulia Pustaka.

Umar, Husein., 2005. Studi Kelayakan Bisnis : Teknik Menganalisis Kelayakan Rencana Bisnis secara Komperehensip., Ed ke-3. Gramedia Pustaka Utama, Jakarta.

BPS., 13.20 /12 / 01 /2016, http:// www.bps.go.id / Subjek / view / id / 60\#subjekViewTab1.

Suku Bunga Bank, 08.30 / 23 / 8 / 2016 http://pusatdata.kontan.co.id/bunga deposito/. 